MICHAŁ CEBULA (D)

University of Wrocław

\title{
BEYOND SOCIAL CLASS AND STATUS. THE NETWORK EMBEDDEDNESS OF MUSIC CONSUMPTION
}

\begin{abstract}
The relationship between stratification and music consumption patterns has become a vibrant field of study in recent years, not only in the sociology of music but also in sociology tout court. It is widely accepted that musical consumption is undergoing profound change, from a tight correspondence between social positions and tastes (the homology argument) to an omnivoreunivore model marked by a greater diversity of preferences among those in higher social strata. What is less understood in both frameworks is how musical consumption is related to an individual's social networks, net of other structural variables (e.g. class or status). Drawing on original quantitative data collected by the author, the paper tries to establish, first, whether diversity of personal networks is conducive to greater heterogeneity in musical preferences and knowledge, and second, what role "weak" and "strong" ties play. It is confirmed that people whose networks are richer in weak connections are more likely to be omnivores while this is not true in the case of strong ties. Some possible explanations of the findings, as well as directions of future studies, are outlined.
\end{abstract}

Keywords: omnivorousness, musical tastes, social network, social capital, stratification of culture 


\section{INTRODUCTION}

Answering the question "What is sociological about music?" Roy and Dowd [2010] make a point that music is a mode of interaction that expresses and constitutes social relations (of different kinds: subcultures, organizations, classes, even nations) with the context-specific intersubjective meanings it delivers and sustains. What is sociological, then, is less the sonic qualities than the social relations that music is both a part of and shapes. Music (as an object or activity - "musicing") may serve to fulfill a wide range of personal and social functions. Its sociological importance lies then in its relations to social and cultural life, in pointing to something beyond itself. Music and its meanings inform people about who they are and where belong to (or want to be a member). From a more individualistic perspective, music is "technology of the self" [DeNora 2000], and is used to construct an identity: to mark and document important aspects of our lives (including memorable events and developing relationships), as well as to structure our daily activities and regulate emotions. At the group level, music can be a "technology of the collective": it serves as an emblem of group belongingness. What is more, music does not simply reflect this group but plays a performative role in defining it, as people gravitate toward those who share similar tastes. On the other hand, tastes can also be used as fences (not bridges) [Douglas, Isherwood 1979], as groups sometimes use music to define themselves against others [Roy, Dowd 2010: 183-191].

This last strand of the sociology of music is elaborated in the social stratification literature, where an extraordinarily influential figure is the French sociologist Pierre Bourdieu. For him [2005: 27]: "nothing more clearly affirms one's 'class', nothing more infallibly classifies, than tastes in music". The "apparent disinterestedness" of musical taste (its foundation in inner, "natural" appreciation) is a convenient vehicle of class differentiation and reproduction. Based on data collected in France in the 1960s, Bourdieu [2005, 2009] shows that distinctions between goods or practices in the universe of culture are also social distinctions that contribute to crystallizing inequalities in society at large. The selections that we make as consumers (every day) - wine or beer, AC/DC or Lady Gaga - are not irreducible personal discernments ("I just like this"), but rather a symptom of the ideology of natural taste which conceals our upbringing, occupation, and social conditions we have been immersed in - in short, our social class [Prior 2013: 182]. The strength of Bourdieu's approach is the focus on how cultural tastes and practices, rather than being epiphenomena of class structure, themselves constitute processes of exclusion and marginalization. Dominant 
groups in society seek to maintain and legitimate their privileges by monopolizing and appropriating some resources (including the cultural and symbolic) and by exerting symbolic violence. Thus, only those who have acquired suitable dispositions (and stock of cultural capital) can feel at home with esoteric culture and display an understanding of the language needed to talk about it, while those with low levels of cultural capital are disenfranchised and feel out of their depth. Consequently, Bourdieu's model of stratification is seen as underpinning the homology argument which states a high association between social positions and position-takings (lifestyles) in such a way that those in higher social strata tend to prefer (reject) what is traditionally accepted as highbrow (lowbrow) music, while those in lower social strata prefer (reject) lowbrow (highbrow) [Chan, Goldthorpe 2007: 1-2].

Despite Bourdieu's immense influence, scholars have observed over time a trend in musical consumption that differs somewhat from the view of tight relation between social stratification and taste variables. Influential in this respect were the works of Richard A. Peterson and colleagues [Peterson, Simkus 1992; Peterson, Kern 1996] who coined the term "cultural omnivore" to address an anomaly observed in surveys which showed that people of higher social status were not averse to participating in activities associated with popular culture, in contrast to the elite/mass model of cultural consumption. As DiMaggio [1987: 444] puts it, the number of genres that a person consumes is a function of his or her socioeconomic status. Certain music consumers become more eclectic or "omnivorous" in their tastes by adding diverse cultural forms or activities to their cultural repertoire at an accelerating rate. Although this trend has found strong empirical support across the world ${ }^{1}$ [see Peterson 2005], its theoretical and methodological status remains underdeveloped [Atkinson 2011; Cebula 2013a; Warde et al. 2007; Savage, Gayo 2011; Tampubolon 2008, 2010]. In particular, a matter of some debate is to what extent this taste regime challenges Bourdieu's legacy. On the one hand, the omnivore thesis is based on a loosening of the tight bonds that exist between social origins and musical taste, and omnivores are seen as essentially tolerant individuals, concerned more with self-realization than with setting down status markers and creating symbolic boundaries [Chan, Goldthorpe 2007]. On the other hand, the omnivore argument still posits at least some relationship between musical taste and stratification. Being omnivorous might also be the latest strategy of distinction amongst

1 In the Polish context, research conducted by Grodny, Gruszka and Łuczaj [2013] showed the opposite trend, namely the narrowing of musical taste (by those named "the highbrows"). 
higher class consumers - a way of displaying one's "cosmopolitan" appetite for a range of cultural forms (see Bourdieu's depiction of the new petit-bourgeoisie in "Distinction"). Lizardo and Skiles [2012] argue that positing homology and omnivorism as contradictory views misunderstands Bourdieu's conceptualization because the very idea of distinction lies not in exclusive highbrow preferences but in the command which individuals have over their aesthetic disposition, that is, in their capacity to constitute common objects or experiences in an aesthetic way. Elements of popular culture are gentrified and incorporated (sometimes in elaborate ways) into the dominant status-group culture.

Regardless of competing hypotheses and data interpretations, the common denominator of the structural frameworks of musical consumption is their focus on the link between social positions (classes or statuses) and cultural tastes or practices (with no reference to personal ties). However, the latter may be claimed to be a crucial nexus (as a cause or an effect) of cultural dispositions and preferences. Networks are an important component of our collective identities and a "tangible" marker of social distances [Chan, Goldthorpe 2004], so studying them may supplement and improve our understanding of the processes of social exclusion and inclusion and thus social structuration and reproduction. Network perspective may be helpful in explaining the phenomenon of "omnivorousness" because as DiMaggio [1987: 444] hypothesized, people with wide-ranging networks develop tastes for the widest variety of cultural forms.

Some passing references to the networks-culture link (or, in Bourdieu's terms, mutual conversions between social and cultural capital) were present when Bourdieu analyzed people who were members of a golf club in "Distinction" [2005: 273, 354-355] or reflected on the role of social habituses in "theoretical" class formation. In the former text, he intimated that elite golf club affiliation may be helpful in the practice of business life by giving favors, delivering information, exerting influence, or providing "credit" and recognition, etc. Although social capital is one of the main powers (forms of capital) structuring the social space, in keeping with theory [Bourdieu 1997], in empirical research [Bourdieu 2005], the concepts of economic and cultural capital perform the entire analytical work, while social capital remains in the background [Cvetičanin, Popescu 2011]. Nevertheless, it is plausible to infer that the shared dispositions and patterns of consumption reported in "Distinction" were generated and reinforced through interpersonal contact, especially if we conjure up the concept of habitus. According to Bourdieu [1987], the affinities of habituses (that is, unconscious dispositions stemming from similar life conditions) are at the root of all processes of cooptation, 
including friendship, love or marriage. People who "speak the same language", "see the world in a similar way" or plump for similar music records have every chance of partnering up [Prior 2013: 183, 185].

Following this line of reasoning, the article seeks to place networks into the understanding of music consumption (including the omnivorous pattern) through examining different network parameters (such as size, diversity and strength of ties) independently of other factors (e.g. social class). In the next section, I describe a network-based theory of social capital and point out to what extent such a theory may be helpful in exploring musical consumption patterns. Following that, I summarize the main research stances on the mutual relationships between networks and culture variables, namely the diffusion explanations that causally privilege preexisting relations and the selection explanations that causally privilege culture. These conceptualizations, along with some previous research, lay the groundwork for hypotheses which are then explored on the data obtained from a non-representative sample of Wrocław inhabitants in 2016. After presenting the main findings, I outline the general implications of the results and point to some limitations of the study.

\section{SOCIAL CAPITAL, SOCIAL NETWORKS AND CULTURE - OLD AND NEW APPROACHES}

Although the literature on social capital has grown exponentially and the term has been applied in numerous contexts (such as job-finding, education, stratification, health), we can admit, following Lin [2001: 24; Lin, Erickson 2008: 4] that the general premise acknowledged by all scholars who contributed to the theory [Putnam 2008; Coleman 1988; Bourdieu 1997; Portes 1998] is that social capital is a network-based phenomenon, something which is vested in personal contacts and interpersonal connections - it is a matter of who knows and recognizes whom, and that people (individually or collectively) can accrue benefits from this connectivity. Thereafter, there is little agreement. It is beyond the scope of this article to elaborate all uses and conceptualizations of the term under study. Suffice it to say, social capital may be conceptualized more in a collective way as a form of social organization. This can be through interpersonal trust, norms of reciprocity and mutual aid, and social involvement, which can improve the efficiency of society by facilitating coordinated actions (such as in the Coleman-Putnam tradition). Alternatively, it can be more in the individualistic terms, as an asset attributable to people that they use for actions [Lin 2001]. Because I am interested in personal 
tastes in music (not in collective action), I follow the framework proposed by Lin but add some qualifications.

For Lin [2001; 2008], social capital shares the same features as the general concept of capital (found, for example, in the Marxist tradition). As a concept, it represents investment and possessing resources of value in a given society. Likewise, social capital may be defined as an investment and the use of embedded resources in social relations for expected returns [Lin 2000: 786]. Thus, one can count as components of social capital: (1) the quantity and/or quality of resources that an actor (be it an individual or a collective) can access or use through (2) its location in a social network. ${ }^{2}$ The first conceptualization of social capital emphasizes resources (embedded in social relations) [Lin 2008; Van Der Gaag, Snijders 2005]. The second conceptualization emphasizes locations in a network or network characteristics (e.g. density, closure, size, strength of ties) [Burt 2001; Marsden 1987]. For Lin [2008], social capital amounts to social resources and should be distinguished from social networks per se. Rather, network features are important and necessary antecedents exogenous to social capital which may increase or decrease the likelihood of having a certain quantity or quality of resources embedded. This stance seems to be too narrow, as it may be argued that holding a certain position in the structure of connections can be an asset on its own. As it was proposed by Ronald S. Burt [2001], better-connected people enjoy higher returns. From the point of view of the aim of this paper, it is important to know what kind of social connectivity is conducive to what types of music preferences. Some commentary is needed as far as the theoretical background of Lin's undertaking is concerned. His perspective is strongly embedded in the theory of social action or, more concretely, in rational action theory. Social capital may be envisioned as an investment by individuals in interpersonal relationships useful in the "markets". It follows that "ego is cognitively aware of the presence of the resources in her or his relations and networks and makes a choice in evoking the particular resources" [Lin 2001:25]. This assumption may be questioned on the grounds of the philosophy of action proposed by Bourdieu [2009] in such terms as "habitus" or "field". It is Bourdieu's way of explaining how action tends to follow patterns without this being the result of either wilful strategizing or mechanical determination [Prior 2013: 183]. In the consumption domain, people may reap benefits from social contacts (e.g. knowledge, tastes) without any intended search for them. Such an effect may reflect the informal

2 This framework is basically consistent with the definition of social capital provided by Bourdieu [1997: 51]. 
workings of social capital, its "invisible hand". ${ }^{3}$ Furthermore, Lin's theory is more focused on cases where the access to and use of resources accrued from contacts are temporary and borrowed; for example, when a friend uses his/her position or network to help ego to find a job. These resources are "borrowed" and useful to achieve ego's particular goal, but they remain the property of the friend or his/her friends [Lin 1999: 468]. However, we may argue that ego's music tastes and practices are rather a durable effect of exposure to "significant others" (via social ties) or at least are sustained by joint participation. Music consumption is then considered more in terms of social influence or socializing than merely of temporary support.

To sum up, I find social networks (or the network theory of social capital) to be an adequate conceptual tool for the analysis of music consumption as it offers a set of rigorous analytical techniques and measures which are potentially an avenue for exploring taste patterns, knowledge and practices [Warde, Tampubolon 2002]. Focusing on the parameters of social networks, such as size, variety, or type of tie, it is possible to explain different configurations of consumption preferences and activities. What needs to be addressed is the causal direction of the relationship between culture (here music) and social networks as well as the mechanisms governing their mutual interaction.

One of the central ideas in the social networks literature is that individuals who are socially connected bear a resemblance to one another. This hypothesis, called the "homophily principle" [McPherson, Smith-Lovin, Cook 2001], does not judge what the characteristics underlying the relationship are, however. Conventionally, the propensity of networks to concentrate around people with common features has been restricted to structural parameters such as race, sex or social class. Cultural elements, such as tastes and values, were not acknowledged as the primary basis of network formation. Rather, it has been argued that social networks are "the infrastructures of society", causally responsible for taste formation via social influence or diffusion processes [cf. Mark 1998]. The so-called "traditional network model" [Lizardo 2006] has been attacked on at least two grounds, however: (1) the acknowledgment that social networks are themselves culturally constituted, and (2) empirical evidence that network structure is itself fluid and dynamic [Puetz 2015]. This perspective enables scholars to privilege cultural dispositions as a plausible causal variable. In practice, these two models are not

3 Lin [2008] also noticed in his later work that social networks may by beneficial without any particular action on the side of the actor (e.g., when social networks provide routine but unsolicited job information). 
mutually exclusive, as longitudinal studies show [Lewis, Gonzales, Kaufmann 2012]. As Kandel [1978] proved, friendship ties result both from prior attributes that attracted ego to alter and from alter's influence in their continued association. The task for sociologists is to specify the circumstances under which a given causal effect occurs.

If we agree that tastes (our cultural portfolio) are "network opportunity structures" we must ask a new question: "How do people actually mobilize their cultural resources to form personal networks?" There are at least two general mechanisms explaining the connection [Puetz 2015: 443]. According to one mechanism, culture or consumer goods provide the stuff of everyday sociability [DiMaggio 1987: 443, 444; Lizardo 2016]. Our tastes, interests and experiences in music are used as a medium of interactional exchange, providing material for conversation ritual at the micro-interactional order [Collins 2011]. As DiMaggio [1987: 443] argued, it was no accident that the emergence of rock and roll as the ritual language of adolescents coincided with their increased mobility (e.g. by automobiles), which brought them face to face with peers beyond their towns and immediate communities. In contrast, Vaisey and Lizardo [2010] have seen "consumer good" more as an interactional hook, a clue which others can treat as signaling the relevant membership category. Drawing on Bourdieu's idea that a lot of what is cultural is "embodied, tacit, largely unconscious and composed of fast and 'hot' cognitive-affective complexes" [2010: 1599], they pointed out that individuals have effective snap-judgment reactions to others' self-presentational styles and use these automatic cognitions to build their personal ties. Whether sociability or snap-judgment is relevant as a mechanism probably depends upon the good's capacity to initiate conversation (as cultural goods, e.g. movies in contrast to material things like clothes).

\section{HYPOTHESES}

Regardless of which mechanisms are operating in the music domain (I think both), what seems to be beyond discussion is that our tastes, pursuits or knowledge are somehow related to whom we keep in touch with or where we belong [Cebula 2015; Erickson 1996; Kane 2004; Lizardo 2006; Relish 1997; Widdop, Leguina 2015]. What is less known is how different profiles or dimensions of cultural tastes are linked to variations in network characteristics. For example, what configuration of social ties is conducive to what types of musical interests or preferences? This paper regards network variables and hypothesizes how they are connected to music consumption (especially to musical omnivorousness). 
Network size and heterogeneity (variety) are key concepts in the literature on social networks [Marsden 1987]. Network size is the quantity of alters with whom ego has a specified relationship. It can be interpreted as a measure of social integration, prominence or activity. Network heterogeneity taps into the diversity of people an individual can contact within his or her interpersonal environment and implies integration into several spheres of society, which is deemed advantageous for instrumental actions like gathering information [Marsden 1987: 124]. On the grounds of cultural consumption, Erickson [1996] noted that people with varied connections (measured by social class diversity) know more about different types of culture and develop omnivorous tastes that allow them to respond in different social settings. For her, the most widely useful cultural resource was cultural variety, which was closely linked to network variety: "The more diverse the set of $(. .$.$) contacts one has, the more variety of culture one will encounter and hence$ maintain or learn" [1996: 247]. According to Lizardo [2006], causality can also run from cultural preferences and dispositions to social contacts because, in order to maintain diverse networks, people must command a wide variety of cultural tastes. To reveal why this is so, Kane [2004] put forward three explanations. Network diversity increases the odds of exposure to diverse cultural resources and activities which can be assimilated; it may also have a direct effect on personality by shaping tolerance and openness to new experiences and materials. Finally, omnivorous orientation and diverse networks may indicate an underlying desire for cosmopolitanism, attributable to people with higher social position. Thus, the link between culture and network would be mediated by social status.

Summarizing these findings, I hypothesize that people with more varied personal networks will present more omnivorous musical tastes controlling for structural variables (e.g. social class) (H1).

While diverse networks might be the key to disentangling the omnivorous tendency in musical consumption, the specificity of this network might also be crucial [Widopp, Leguina 2015]. As we know, social capital or social networks may be characterized along with different dimensions. One of the most seminal concepts in this regard is the distinction made by Putnam [2008] between bonding (or exclusive) and bridging (or inclusive) social capital. The former, which is inward-looking, tends to reinforce exclusive identities and homogenous groups (and is "good for undergirding specific reciprocity and mobilizing solidarity"). The latter (outward-looking) encompasses people across diverse social cleavages and gives access to external assets and information [Putnam 2008: 40-41]. This idea echoes Granovetter's [1973] influential hypothesis about the "strength of weak ties". The author hypothesized that the stronger the tie between any 
given dyad, the larger the proportion of people to whom they will both be tied (connected by a weak or strong tie). In effect, strong ties are among people who know each other and create one social circle. In contrast, if we are connected to others by weaker ties, there is some likelihood that these ties are bridges (i.e., they link people from different social circles). His main argument is that "those to whom we are weakly tied are more likely to move in circles different from our own and will thus have access to information different from that which we receive" [1973: 1371]. Although he was looking at the employment market, the same rationale can be applied to music consumption [Widdop, Leguina 2015]. The network structure of weak ties allows individuals to tap into more diverse musical genres and act as conduits for influence (musical socialization).

Hence, I suggest that the greater the number of weak ties (but not strong ties) in someone's personal network, the higher the probability that he or she will be a musical omnivore and familiar with more musical items (e.g. songs) (H2).

The last hypothesis derives from Putnam's notion of social capital operationalized by associational membership (so-called formal social capital). There have been few attempts to apply Putnam's notion to explanations of taste, yet it does have potential resonance with elaborations of the cultural omnivore thesis. Following Warde and Tampubolon's [2002] study on leisure activities, I hypothesize that wider exposure to social groups (via associational membership) may give an opportunity to learn more diverse tastes. Participating in voluntary associations (especially those with a mixed line-up) might stimulate our musical activities (or interests) directly - leading to invitations to participate in new fields of consumption, or indirectly - by increasing access to information and advice about consumption or by increasing awareness of differences of tastes between individuals. The opposite dependence may also be true, when our cultural resources operate as sociable "currency".

Therefore, the following hypothesis is proposed: Associational membership increases the probability that a person will display a taste for a greater variety of music (H3).

\section{DATA AND VARIABLES}

The empirical material for this article comes from the Socially Embedded Consumption survey ${ }^{4}$ carried out in 2016 on a non-representative sample of working Wrocław inhabitants between 18 and 75 years of age. The data was

4 The research project was financed from a grant awarded by the Faculty of Social Sciences, University of Wrocław (no. 0420/1814/16). 
collected by means of face-to-face questionnaire interviews, resulting in a sample size of $\mathrm{N}=300 .{ }^{5}$ Because the aim of the research was to investigate the social underpinnings of consumption patterns (including social class), I decided to use a specific sampling strategy. The respondents were recruited on the basis of their current occupation that, in keeping with the social stratification literature [Domański 2007], remains the best available (and most economical) indicator of general social standing as it combines the main dimensions of the social structure (including inputs such as education and outputs such as income). It follows that the population was narrowed to working people. ${ }^{6}$ Second, the sample was split into three main occupational strata, each one comprising one hundred respondents. These strata were constructed on the basis of the Social Classification of Occupations devised by Domański, Sawiński, and Słomczyński [2007] and were used as a proxy measure of social class (named conventionally as A, B and C). ${ }^{7}$

The data set is well suited to the purposes of this study as it contains detailed information on personal social networks, music preferences and knowledge, and social standing (social class and status). The latter are treated as control variables.

To asses music consumption patterns, the respondents were asked a series of questions on liking seventeen musical genres using a 5-point Likert scale (ranging from 1 - "dislike very much" to 5 - "like very much"). ${ }^{8}$ The responses were then combined to create one measure capturing the range of musical preferences. Conventionally, "omnivorousness" was operationalized as the number of items that the respondents liked (were familiar with or actively participated in) [Peterson 2005; Warde, Wright, Gayo-Cal 2007] but it may be argued that the very idea of this cultural pattern, as raised by Peterson and his co-authors, lies in

5 The effective sample size is 275 as 25 respondents claimed not to listen to music at all.

6 In this way, the variance of data was limited to some categories as the number of cases was controlled (for example, the unemployed were excluded). It allowed me to address the problem of too few cases within the variable categories.

7 Class category A included chief executive officers, managers, business owners (employing at least five people), and professionals and specialists like doctors, lawyers, artists, professors, assistant professors etc. Category B was composed of small owners (employing from one to four people) and self-employed owners, technicians and specialized office workers, other middle-level, non-manual workers, and partially of sales and service workers (those who were well-qualified). Category $\mathrm{C}$ comprised sales and service workers, skilled, semi-skilled, and non-skilled manual workers.

8 The list of musical genres included: pop music; rock; sacred, choral or organ music; country; classical music or opera; dance music, techno or house; disco-polo; jazz; blues, soul; electronic music; hard rock and heavy metal; rap, hip-hop or alternative music; folk music; R \& B; reggae; world music; chanson music, and sung poetry. 
the composition of what is consumed or in crossing cultural boundaries - usually those associated with the "highbrow" and the "lowbrow". In the study, musical genres were divided into two groups according to their "legitimacy", and the number of pairs of each yielded a measure of omnivorousness [cf. Berghman, van Eijck 2009: 359]. ${ }^{9}$

The second index of omnivorousness referred to the respondents' familiarity with seven musical works. ${ }^{10}$ The respondents' task was to indicate these works on the list which he or she had listened to or at least heard of the title. Then the mean score of answers was calculated ranging from 0 ("have not heard of") through 1 ("have only heard of the title") to 2 ("have listened to").

Although the measurement of social capital or social networks is well established in the sociological literature [Lin, Erickson 2008], its usage by sociologists of culture is often scarce (especially in the Polish context, where the problem of the culture-network link has just started to develop empirically) [Cebula 2015; Domański 2016]. Although these tentative studies show promising results, they often relied on proxy network indicators, and thus they increase the desire for conceptual refinement and greater precision in measuring network characteristics. In this study, the social network is measured using the Position Generator [Lin, Erickson 2008], which remains one of the most reliable network tools. This instrument asks people about their network members' occupational positions, which are assumed to be good indicators of social resources. As Erickson and Lin [2008: 9] proposed: "the more that a person knows people from all levels of the occupational hierarchy, the more likely it is that a person has access to a wide range of potentially useful resources". In my study, the respondents were shown a list of 14 occupations ${ }^{11}$ and then asked to indicate for each occupation whether

9 The legitimacy of genres was assessed by analyzing their correlations with the main stratification variables (such as education, status, income, etc.) and by principal component analysis. In effect, all genres were divided into two categories: one comprising sacred, choral or organ music; country; classical music or opera; jazz; blues and soul; world music and chanson music, sung poetry. The second group included pop music; rock; dance music, techno or house; disco-polo; hard rock and heavy metal; rap, hip-hop or alternative music; and R\&B. Reggae, folk and electronic music were counted separately and added to the final index. The index was counted if the respondent declared a liking for any given music genre (joint categories 4 - "like a little bit" and 5 - "like very much").

10 These works included "Ona tańczy dla mnie" by Weekend, "Lose Yourself" by Eminem, "Smells Like Teen Spirit" by Nirvana, "The Four Seasons" by Vivaldi, "Kind of Blue" by Miles Davis, "Poker Face" by Lady Gaga and "Małgośka" by Maryla Rodowicz.

11 The list comprised: lawyer, doctor, scientist, teacher, IT specialist, businessman/owner (other than respondent's employer), local politician, journalist, mechanic, book-keeper/accountant, artist/actor/musician, counter clerk, nurse, construction worker or finisher. 
or not they had "family members, friends or acquaintances with that occupation." My approach to the Position Generator is to calculate two measures: (1) the volume of strong ties, by counting the number of family members or friends known in the presented occupations; (2) the volume of weak ties, operationalized by the number of acquaintances. ${ }^{12}$ Additionally, the strength of ties was gauged by three open questions about the number of people with whom the respondent keeps in contact regularly (at least a few times a year). These questions concerned, separately, family members (apart from those at home) (a proxy for "strong ties") and, taken together, friends and acquaintances (a proxy for "weak ties").

Also, other measures of social connections or social participation were used, among which the diversity of ego's network was of great importance. Following Growiec's [2015] operationalization of bridging social capital as embracing people with different social characteristics than ego, the respondents were asked whether they had friends or acquaintances who are older or younger than them, hold divergent political beliefs, or differ in social status, etc. The positive answers were subsequently summarized in one index of social network diversity. ${ }^{13}$

To explore the extent to which formal social capital (in Putnam's notion) is connected to music preferences, I used a single question on the number of associations (like the political party, professional society, labor union, parent-teacher association etc.) to which a respondent claims membership. ${ }^{14}$

The analytical strategy employed in the paper is to assess the relative importance of network variables in explaining musical tastes and knowledge against the background of socio-demographic variables traditionally seen as music consumption antecedents ${ }^{15}$ [Bourdieu 2005; Cebula 2013b; Chan, Goldthorpe 2007]. To that end, I used OLS regressions to model all explanatory variables in one equation.

12 The number of acquaintances was then divided by the number of possible weak ties (that is, potential ties remaining after subtracting strong ties). The final ratio is then independent of the strong ties measure.

13 The wording of the question was: "Among your friends and acquaintances, are there people: a) who are largely of a different age than you?, b) who hold different political views than you?, c) who occupy different material status than you?, d) who prefer different kinds of music, literature and entertainment than you?, e) who lead a lifestyle different to you?, f) who speak a different language to you?, g) who are outside of your circle of friends from your neighborhood or school?, h) who have different sexual orientation than you?". The answer scale ranged from 1 - "absolutely not" to 5 - "absolutely yes". The final index was calculated on the basis of principal component analysis.

14 The scale ranged from 0 - "no membership" to 4 - "membership in at least four organizations".

15 The main independent variables are the following: social class (measured by Standard Classification of Occupation), age, cultural capital (indicated by the fact whether or not a respondent 


\section{RESULTS}

An initial overview of the descriptive statistics reveals that the most popular (preferred) musical genres include pop music (Mean $=3.64$ on the 5-point scale from "dislike very much" to "like very much"; $\mathrm{SD}=1.05)$, rock $(\mathrm{M}=3.43$; $\mathrm{SD}=1.09)$, disco-polo $(\mathrm{M}=2.95 ; \mathrm{SD}=1.39)$ and dance music $(\mathrm{M}=2.79$; $\mathrm{SD}=1.24$ ), all which can be classified as "lowbrow" culture. The relatively least commonly liked are sacred, choral or organ music $(\mathrm{M}=2.28 ; \mathrm{SD}=1.13)$, country $(\mathrm{M}=2.29 ; \mathrm{SD}=1.12)$, folk $(\mathrm{M}=2.33 ; \mathrm{SD}=1.12)$ and hard-rock and heavy metal $(\mathrm{M}=2.46 ; \mathrm{SD}=1.26)$. To understand the structural antecedents of musical taste, a correlation analysis was conducted. As expected, classical music or opera, jazz, and blues/soul have a significant (positive) correlation with social class position (respectively Eta coefficients: $0.221,0.226,0.204$ ), a corollary of which is that some music types serve the function of reflecting and upholding status boundaries. On the opposite pole of cultural hierarchy we can discern disco-polo and, to a lesser degree, pop music, as they correlate negatively with status attributes such as economic standard of living ${ }^{16}$ (in the case of disco-polo: rPearson $=-0.224 ; p<0.001)$, cultural capital, as assessed by the educational background of the parents ${ }^{17}(\mathrm{r}=-0.143 ; \mathrm{p}<0.05)$, and book reading/collecting ${ }^{18}$ $(\mathrm{r}=-0.125 ; \mathrm{p}<0.05)$ as regards pop music.

Because the main focus of the paper is to assess the role of the socio-demographic and network variables for predicting the breadth of an individual's musical tastes, I performed a multivariate analysis by means of OLS regressions. Table 1 shows the standardized (Beta) coefficients which inform us about the relative effects of the analyzed predictors on the "dependent" variable (musical omnivorousness by composition). ${ }^{19}$

attended a course, lecture or conference during the last year to expand his or her knowledge or to upskill), social status (self-assessed on a 10-point scale where 1 meant "very poor" and 10 - "very good) and economic capital (measured by the financial condition of the respondent's household; this condition was evaluated on a five-point scale from "we are living very poorly..." to "we are living very well...").

16 This variable was measured by possession of 11 durable consumer goods in the household, such as a dishwasher, LCD TV set, home cinema, DVD/Blu-ray player, portable computer (laptop, notebook), coffeemaker etc.

17 This is a linear combination of the education of the respondent's father and mother.

18 This indicator was calculated as a linear combination of the number of books read in the last year and the number of books collected in the home.

19 Numbers in parentheses in the table are $\mathrm{t}$ statistics. 
TABLE 1. Predictors of musical omnivorousness (OLS regression coefficients)

\begin{tabular}{|c|c|c|c|c|}
\hline Variables & Model I & Model II & Model III & Model IV \\
\hline \multirow{2}{*}{ (Constant) } & $-^{*}$ & -** & -*** & - \\
\hline & (2.299) & $(-3.332)$ & $(-4.037)$ & $(-1.209)$ \\
\hline \multirow{2}{*}{ Class A } & $0.204 * *$ & 0.053 & 0.033 & 0.033 \\
\hline & $(2.972)$ & $(0.760)$ & $(0.494)$ & $(0.493)$ \\
\hline \multirow{2}{*}{ Class B } & 0.126 & 0.063 & 0.030 & 0.065 \\
\hline & (1.874) & $(0.960)$ & $(0.473)$ & (1.036) \\
\hline Class C & ref. & ref. & ref. & ref. \\
\hline $18-25$ years & ref. & ref. & ref. & ref. \\
\hline \multirow{2}{*}{$26-30$ years } & 0.072 & 0.123 & 0.084 & 0.119 \\
\hline & $(0.839)$ & (1.507) & $(1.092)$ & $(1.560)$ \\
\hline \multirow{2}{*}{$31-35$ years } & 0.071 & 0.077 & 0.032 & 0.083 \\
\hline & $(0,819)$ & $(0.942)$ & $(0.417)$ & $(1.070)$ \\
\hline \multirow{2}{*}{$36-40$ years } & $0.269 * *$ & $0.302 * * *$ & $0.223 * *$ & $0.248 * *$ \\
\hline & $(3.088)$ & $(3.671)$ & $(2.863)$ & $(3,156)$ \\
\hline \multirow{2}{*}{$41-47$ years } & $0.306 * * *$ & $0.324 * * *$ & $0.232 * *$ & $0.257 * *$ \\
\hline & (3.743) & $(4.210)$ & $(3.155)$ & $(3.473)$ \\
\hline \multirow{2}{*}{48 or more years } & 0.081 & 0.153 & $0.146 *$ & $0.173 *$ \\
\hline & $(0.996)$ & (1.969) & (1.994) & $(2.331)$ \\
\hline \multirow{2}{*}{$\begin{array}{l}\text { Cultural capital (taking part } \\
\text { in a course) }\end{array}$} & & $0.183 * *$ & 0.102 & 0.097 \\
\hline & & (3.347) & (1.923) & $(1.840)$ \\
\hline \multirow{2}{*}{ Subjective social status } & & $0.288 * * *$ & $0.185 * *$ & $0.176 * *$ \\
\hline & & $(4.869)$ & $(3.222)$ & $(3.086)$ \\
\hline \multirow{2}{*}{$\begin{array}{l}\text { Number of strong ties } \\
\text { (Position Generator) }\end{array}$} & & & 0.067 & 0.036 \\
\hline & & & $(1.180)$ & $(0.631)$ \\
\hline \multirow{2}{*}{ Number of weak ties - relative (PG) } & & & $0.199 * *$ & $0.175^{* *}$ \\
\hline & & & $(3.458)$ & $(3.080)$ \\
\hline \multirow{2}{*}{ Variety of personal network } & & & $0.194 * * *$ & $0.208 * * *$ \\
\hline & & & $(3.624)$ & $(3.899)$ \\
\hline \multirow{2}{*}{ Associational membership } & & & $0.128 *$ & 0.094 \\
\hline & & & $(2.424)$ & $(1.780)$ \\
\hline \multirow{2}{*}{$\begin{array}{l}\text { Number of family members with } \\
\text { whom one keeps in touch (strong ties) }\end{array}$} & & & & 0.003 \\
\hline & & & & $(0.054)$ \\
\hline
\end{tabular}


TABLE 1. (cont.)

\begin{tabular}{|c|c|c|c|c|}
\hline Variables & Model I & Model II & Model III & Model IV \\
\hline \multirow{2}{*}{$\begin{array}{l}\text { Number of friends and acquaintances } \\
\text { with whom one keeps in touch } \\
\text { (weak ties) }\end{array}$} & & & & $0.148 *$ \\
\hline & & & & $(2.498)$ \\
\hline \multirow{2}{*}{$\begin{array}{l}\text { Discussing important matters with } \\
\text { friends and acquaintances }{ }^{\mathrm{a}}\end{array}$} & & & & $-0.138 * *$ \\
\hline & & & & $(-2.693)$ \\
\hline \multirow{2}{*}{$\begin{array}{l}\text { Frequency of meeting up with } \\
\text { non-home relatives }\end{array}$} & & & & $-0.109 *$ \\
\hline & & & & $(-2.080)$ \\
\hline Adjusted $\mathrm{R}^{2}$ & 0.115 & 0.215 & 0.317 & 0.353 \\
\hline $\begin{array}{l}\mathrm{F} \text { - change (comparing to previous } \\
\text { model) }\end{array}$ & - & $\begin{array}{c}\Delta \mathrm{F}(2.265)= \\
18.037 \\
\mathrm{p}<0.001\end{array}$ & $\begin{array}{c}\Delta \mathrm{F}(4.261)= \\
10.889 \\
\mathrm{p}<0.001\end{array}$ & $\begin{array}{l}\Delta \mathrm{F}(4.257)= \\
\quad 4.647 \\
\mathrm{p}<0.01\end{array}$ \\
\hline
\end{tabular}

$* \mathrm{p}<0.05 \quad * * \mathrm{p}<0.01 \quad * * * \mathrm{p}<0.001$

a The statement measured on a 5-point scale ranging from 1 - "never" to 5 - "very often".

${ }^{\mathrm{b}}$ Answers on a 6-point scale ranging from 1 - "less often than once a year" to 6 - "at least once a week".

Source: own work.

In the first step of the analysis, the social class position (dummy variables with $\mathrm{C}$ as a reference category) and age were taken into account, revealing that both are connected to the variable being studied. Individuals who occupy the highest social positions (e.g. managers, specialists, owners) as well as from the age category 36-47 are more likely to be omnivore consumers of music. It should be noticed that the age variable displays curvilinearity, which implies that the youngest and oldest ends of the age spectrum display less diversity in musical preferences than the middle-aged categories. The effect of social position is the same as in previous studies [Bourdieu 2005; Cebula 2013b; Chan, Goldthorpe 2007; Pabjan 2009], but if Model I is expanded to include cultural capital (dummy variable) and social status, neither of the class position variables remains significant as a predictor. It may be argued that the class effect is mediated by cultural resources and related to hierarchical standing. Some authors argue that the class concept is a multidimensional phenomenon which comprises "coherent and institutionalized bundles of endowment (e.g. educational levels), working conditions (e.g. amount of autonomy), and rewards packages (e.g. income)" [Petev 2013: 637]. In other words, items which are treated separately in my study (class and cultural capital), are held by others as constituent factors of class position. From this point of view, these findings do not challenge the idea 
of class-based cultural consumption, if we agree that other indicators of social position are a proxy for class membership.

The addition of the network variables in further steps of the analysis significantly improves the fit of the models with the adjusted R-square rising from 0.215 to 0.317 (Model III) and from 0.317 to 0.353 (Model IV), thus proving the general statement that social contacts play a significant role in musical consumption (net of other factors). More precisely, those people whose personal networks are more diversified display a greater propensity to cross musical boundaries in their consumption, as evidenced by the Beta coefficients $(B=0.194 ; \mathrm{p}<0.001$ in Model III and $\mathrm{B}=0.208 ; \mathrm{p}<0.001$ in Model IV). The results support my first hypothesis (H1) and correspond with the statement of Erickson [1996: 247] that "network variety is one important source of cultural variety" but with the qualification that the reverse causal direction is also possible [Lizardo 2006]. Also, the coefficients for "weak ties" variables are positive in sign, indicating that the number of weak ties (but not strong ties) increases the likelihood of being an omnivore musical consumer. In other words, those who maintain more weak connections (i.e., have a greater number of friends and acquaintances) are also those who have a taste for many musical genres. This is not true for individuals socializing with family or who have a greater number of occupations accessed via strong connections (as predicted in $\mathrm{H} 2$ ). What is striking is that close relations may even have a negative impact on the breadth of "musical horizons", as evidenced by the negative coefficients for the frequency of discussing "important matters" with friends and acquaintances $(\mathrm{B}=-0.138 ; \mathrm{p}<0.01)$ and the frequency of social contacts with relatives $(B=-0.109 ; p<0.05)$. Both variables are assumed to capture intimate ties which, according to Granovetter [1973: 1361], are constituent parts of strong ties, along with the amount of time, emotional intensity and reciprocal services.

The predominance of weak ties in predicting musical omnivorism may result from the assertion that weak ties are more often "bridges", and thus useful in searching for and obtaining more diversified resources [Granovetter 1973; Putnam 2008]. Cognately, strong ties that are conducive to dense networks are better at preserving or maintaining assets [Lin 2001: 27]. Living in dense and closed networks facilitates the acquisition of more redundant cultural knowledge that strengthens cultural (musical) preferences and identity.

Another question concerned the effect of associational membership. I predicted that participation in voluntary organizations may create an opportunity to learn more diverse tastes. This hypothesis (H3) is only partially supported, as the influence of the variable declines to insignificance when other network measures are added to the model (compare Models III and IV). It is probably due 
to the high correlation between predictors that catch the overlapping dimension of social capital.

To find more robust evidence of the link between social networks and music consumption, a second set of OLS regressions models was fitted with the familiarity with musical works (index of musical knowledge) as the dependent variable $^{20}$ (Table 2$)$.

TABLE 2. Predictors of familiarity with musical works (OLS regression coefficients)

\begin{tabular}{|c|c|c|c|c|}
\hline Variables & Model I & Model II & Model III & Model IV \\
\hline \multirow{2}{*}{ (Constant) } & $-* * *$ & $-* * *$ & $-* * *$ & -*** \\
\hline & $(23.242)$ & $(12.345)$ & (11.894) & $(8.378)$ \\
\hline \multirow{2}{*}{ Class A } & $0.246 * * *$ & 0.133 & 0.096 & 0.117 \\
\hline & $(3,883)$ & $(1.851)$ & $(1.330)$ & $(1.696)$ \\
\hline \multirow{2}{*}{ Class B } & $0.225 * * *$ & $0.191 * *$ & $0.163 *$ & $0.141 *$ \\
\hline & $(3.547)$ & $(2.990)$ & $(2.516)$ & $(2.279)$ \\
\hline Class C & ref. & ref. & ref. & ref. \\
\hline \multirow{2}{*}{ Age (in years) } & $-0.368 * * *$ & $-0.350 * * *$ & $-0.333 * * *$ & $-0.255 * * *$ \\
\hline & $(-6.756)$ & $(-6.552)$ & $(-6.266)$ & $(-4.873)$ \\
\hline \multirow{2}{*}{$\begin{array}{l}\text { Cultural capital (course } \\
\text { partaking) }\end{array}$} & & $0.142 * *$ & $0.117 *$ & $0.115 *$ \\
\hline & & $(2.624)$ & $(2.168)$ & $(2.225)$ \\
\hline \multirow{2}{*}{$\begin{array}{l}\text { The financial condition of the } \\
\text { household }\end{array}$} & & 0.161* & $0.126 *$ & 0.103 \\
\hline & & $(2.590)$ & $(2.037)$ & (1.748) \\
\hline \multirow{2}{*}{$\begin{array}{l}\text { Number of strong ties (Position } \\
\text { Generator) }\end{array}$} & & & 0.000 & 0.018 \\
\hline & & & $(0.008)$ & $(0.315)$ \\
\hline \multirow{2}{*}{$\begin{array}{l}\text { Number of weak ties - relative } \\
\text { (PG) }\end{array}$} & & & $0.203 * *$ & $0.151 * *$ \\
\hline & & & $(3.520)$ & $(2.731)$ \\
\hline \multirow{2}{*}{$\begin{array}{l}\text { Number of family members with } \\
\text { whom one keeps in touch (strong } \\
\text { ties) }\end{array}$} & & & & $-0.155^{* *}$ \\
\hline & & & & $(-3.021)$ \\
\hline \multirow{2}{*}{$\begin{array}{l}\text { Participation in cultural events } \\
\text { with friends and acquaintances }\end{array}$} & & & & $0.190 * *$ \\
\hline & & & & (3.314) \\
\hline
\end{tabular}

20 The mean score of the index is 1.69 (on a scale from 0 to 2 ) and is higher as we ascend the stratification ladder (for Class $\mathrm{C}$ it is $1.54 ; \mathrm{B}=1.75 ; \mathrm{A}=1.76)(\mathrm{Eta}=0.254)$. The most recognized musical works are: "Ona tańczy dla mnie" by Weekend (95\% of the respondents claim to know this) and "Małgośka" by Maryla Rodowicz (93\%); the least recognized are "Kind of Blue" by Miles Davis (64.4\%) and "Lose Yourself” by Eminem (69.8\%). 


\begin{tabular}{|c|c|c|c|c|}
\hline Variables & Model I & Model II & Model III & Model IV \\
\hline \multirow{2}{*}{$\begin{array}{l}\text { Encouragement from friends and } \\
\text { acquaintances to try something } \\
\text { new (e.g. food, sport, hobby) })^{\mathrm{b}}\end{array}$} & & & & $0.140 *$ \\
\hline & & & & $(2.510)$ \\
\hline Adjusted $\mathrm{R}^{2}$ & 0.191 & 0.226 & 0.258 & 0.332 \\
\hline $\begin{array}{l}\text { F - change (comparing to previ- } \\
\text { ous model) }\end{array}$ & - & $\begin{array}{l}\Delta \mathrm{F}(2.269) \\
=7.212 \\
\mathrm{p}<0.01\end{array}$ & $\begin{array}{l}\Delta \mathrm{F}(2.267) \\
=6.682 \\
\mathrm{p}<0.01\end{array}$ & $\begin{array}{l}\Delta \mathrm{F}(3.264) \\
=10.933 \\
\mathrm{p}<0.001\end{array}$ \\
\hline
\end{tabular}

$* \mathrm{p}<0.05 \quad * * \mathrm{p}<0.01 \quad * * * \mathrm{p}<0.001$

a The statement measured on 5-point scale ranging from 1 - "never" to 5 - "very often".

${ }^{\mathrm{b}}$ See above.

Source: own work.

As may be noted, the findings are much the same as in the previous study. First, we can see that age is strongly and negatively correlated with our dependent variable $(\mathrm{B}=-0.255 ; \mathrm{p}<0.001$ in Model IV) which means that the older section in the sample are less familiar with musical works than the younger one. Social class proves to have a positive effect on cultural knowledge although its impact diminishes when additional variables are added. Nevertheless, the members of class B demonstrate systematically broader knowledge of music compared to $\mathrm{C}$ (the reference category). In all three models (beginning with Model II), the coefficients for cultural capital are significant and positive in sign, indicating that general mastery of the cultural domain is closely linked with musical competence. As mentioned above, it corroborates the importance of class division if we assume that cultural resources are part of one's class situation.

The findings reported in Table 2 provide consistent support for the hypothesized link between weak ties and cultural knowledge after controlling for socio-demographic factors (H2). The higher the number of occupations accessed via weak ties (acquaintances) (but not strong ties), the greater familiarity with musical items ( $\mathrm{B}=0.151 ; \mathrm{p}<0.01$ in Model IV). A strikingly different pattern emerges in the case of socializing with family. Those more embedded in the family network are less knowledgeable in musical matters (taking the measure used in the survey) $(\mathrm{B}=-0.155 ; \mathrm{p}<0.01)$. Network volume is a source (or at least a correlate) of cultural variety, but there are rather "weak" connections through which cultural knowledge is transmitted. Kin ties function more as bonding capital; it is this type of capital that might constrain cultural knowledge and preferences.

An open question remains as to the specific mechanisms translating network resources into cultural resources (or conversely). Is it informational, practical or 
based on the encouragement of interest influence? There are some interesting hints in the results that indicate that active assistance in cultural consumption (joint participation) and direct incentives from friends and acquaintances have some relevance $(\mathrm{B}=0.190 ; \mathrm{p}<0.01$ and $\mathrm{B}=0.140 ; \mathrm{p}<0.05$ respectively).

\section{DISCUSSION AND CONCLUSION}

A common theme in the sociology of music is that which pertains to the structural underpinnings of music preferences, practices or dispositions, that is, how our cultural choices both reflect and are utilized to form social boundaries and group identities. Although the relationship between stratification and cultural consumption patterns has received extensive attention in the sociological literature [Bourdieu 2005; Chan, Goldthorpe 2007; Peterson 2005], insufficient attention has been paid to social connections. The paper attempts to provide a more comprehensive picture of musical preferences by building not only on traditional variables but also on new ones (such as personal networks). Music consumption is much more complex than simply basing theoretical assumptions on class and education; it is fundamentally a social act - what genres you attach yourself to, what kind of music you are familiar with, is somehow dependent upon the networks you are embedded in.

The findings reported in the paper show that personal (ego-centered) networks matter for an individual's musical consumption patterns, after controlling for socio-demographic factors. People whose networks are more diverse more often combine those genres in their musical "likings" which originate from different cultural levels (termed "highbrow" and "lowbrow"); in our terms, they are indicative of cultural omnovorism. The number of social connections is also correlated with greater cultural knowledge (here: familiarity with musical works). This evidence supports the results found by Erickson [1996] that network variety is related to cultural variety, but it does not judge what causal relationship is between them. Furthermore, the people who are in this network is not negligible. Following the distinction between "weak" and "strong" ties [Granovetter 1973], it has been shown that it is more the former that link to the omnivorous pattern. Those respondents who can access different occupations in their networks via weak connections, or who socialize with greater numbers of friends and acquaintances, are more likely to tap into a greater variety of musical genres. It is not the case as regards strong ties (e.g. with relatives). According to the theory, weak ties are more likely to be "bridges." In other words, they span larger distances in social space and thereby give access to more diverse resources, information and incentives [Putnam 
2008]. In comparison to previous studies [Cebula 2015; Domański 2016], the analysis provides more comprehensive and nuanced network measures, such as those based on the Position Generator, or on the direct characteristics of ego's alters. Additionally, it includes indicators of formal social capital (associational membership) proving it has some potential in explaining tastes.

However, some limitations of the study must be mentioned. The first is the non-probabilistic sampling strategy which does not allow us to extrapolate the results to the general population (in statistical terms). Nonetheless, the repetitive pattern of findings (congruent with the theory and previous studies) lends credence to the contention that the same dependencies are also present in the general population. The second limitation refers to the causal relationships between variables. To disentangle social influence or the diffusion process from the selection process, we need panel studies [cf. Lewis, Gonzales, Kaufman 2012]. What specific mechanisms explain the connection between social networks and cultural (musical) tastes and practices also remains a blind spot as quantitative research provides correlative data without much insight into the micro-level processes of mobilizing cultural resources in everyday interactions and socializing. A tentative explanation is that attending events with friends and direct encouragement from them are of non-negligible relevance in music consumption. Networks are, in the last instance, composed of and imbued with subjective and cultural meanings and thus amenable to qualitative studies. How do people "manage" their relations with significant others? What kind of meanings do they ascribe to them? What is their cultural "content"? To answer these questions, we need to go beyond the survey data. ${ }^{21}$

Indeed, for some sociologists, the music itself and our encounters with it are far too complex to be conveyed through statistical indices and genre categorizations. Survey measurements, after all, tell us very little about why people like music and how it is involved in their lives. Measuring musical preferences by genre categories (such as pop, rock, country, etc.) may be flawed, or at least inadequate, as it ignores subtle distinctions and meanings made within them (e.g. "difficult" versus "light" classical, "underground" versus "pop" rap music). In fact, we do not know how specific genres are interpreted by the respondents (e.g. what counts as "classical" for one person might not for another) and how they are appreciated (e.g. with irony, aestheticization, passivity) [Atkinson 2011: 171-172]. In this

${ }^{21}$ Some of the problems raised here will be address in the project: "Social structure, networks, and consumption tastes and practices", financed by National Science Centre in Poland (UMO-2016/21/D/HS6/02424). 
case, Holt [1997] has championed more fine-grained measures of musical tastes, for example, instead of asking people only about preferred music categories, it is worth probing the artists or music works they listen to and like, or try to capture the dispositional aspects of cultural behavior (e.g. evaluative criteria). ${ }^{22}$

Another question to be addressed bears on the formal channels and institutions through which music is distributed and experienced. Listening to and appreciating a diverse range of styles become easier with the rise of digital technologies and the evolution of musical venues and events. Digital formats and devices have given users historically unprecedented access to the ever-proliferating body of musical works. This, coupled with the shift of music institutions from static upholders of tightly-bound musical traditions to multisensory spaces offering spectacular consumer experiences, has laid the groundwork for more episodic and eclectic ways to assimilate music [Prior 2013].

Future research should explore how these new modes of music circulation contribute to the diversification of individual cultural repertoires, both independently of as well in conjunction with personal networks.

\section{BIBLIOGRAPHY}

Atkinson Will. 2011. "The context and genesis of musical tastes: Omnivorousness debunked, Bourdieu buttressed". Poetics 39(3): 169-186.

Berghman Michaël, Koen van Eijck. 2009. "Visual arts appreciation patterns: Crossing horizontal and vertical boundaries within the cultural hierarchy". Poetics 37 (4): 348-365.

Bourdieu Pierre. 1987. "What makes a social class? On the theoretical and practical existence of groups". Berkeley Journal of Sociology 32: 1-17.

Bourdieu Pierre. 1997. The forms of capital. In: Education: Culture, economy, society, A.H. Halsey, H. Lauder, P. Brown, A.S. Wells (eds.), 46-58. Oxford: Oxford University Press.

Bourdieu Pierre. 2005. Dystynkcja. Społeczna krytyka władzy sądzenia. Warszawa: WN Scholar.

Bourdieu Pierre. 2009. Rozum praktyczny. O teorii działania. Kraków: Wyd. UJ.

Burt Ronald S. 2001. Structural holes versus network closure as social capital. In: Social capital: Theory and research, N. Lin, K.S. Cook, R.S. Burt (eds.), 31-56. New York: Aldine de Gruyter, 2001.

Cebula Michał. 2013a. „Współczesne formy kulturowych zróżnicowań. Przypadek 'wszystkożerności”". Forum Socjologiczne 4: 111-131.

Cebula Michal. 2013b. „Społeczne uwarunkowania gustów i praktyk konsumpcyjnych. Zbieżność pozycji społecznych i stylów życia czy autonomizacja kultury?". Studia Socjologiczne 3: 97-125.

Cebula Michal. 2015. "Beyond economic and cultural capital: Network correlates of consumption tastes and practices". Polish Sociological Review 4: 455-474.

${ }^{22}$ To tackle this problem, the respondents were asked about familiarity with and preference for concrete musical works (see the methodological part of the paper). 
Chan Tak W., John H. Goldthorpe. 2007. "Social stratification and cultural consumption: Music in England". European Sociological Review 23(1): 1-19.

Chan Tak W., John H. Goldthorpe. 2004. "Is there a status order in contemporary British society?" European Sociological Review 20(5): 383-401.

Coleman James S. 1988. "Social capital in the creation of human capital". American Journal of Sociology 94(Supplement): 95-120.

Collins Randall. 2011. Łańcuchy rytuałów interakcyjnych. Kraków: Nomos.

Cvetičanin Predrag, Mihaela Popescu. 2011. "The art of making classes in Serbia: Another particular case of the possible". Poetics 39(6): 444-468.

DeNora Tia. 2000. Music in everyday life. New York: Cambridge University Press.

DiMaggio Paul. 1987. "Classification in art”. American Sociological Review 52(4): 440-455.

Domański Henryk, Zbigniew Sawiński, Kazimierz M. Słomczyński. 2007. Nowa klasyfikacja i skale zawodów. Socjologiczne wskaźniki pozycji społecznej w Polsce. Warszawa: Wyd. IFiS PAN.

Domański Henryk. 2007. Struktura społeczna, wydanie nowe. Warszawa: WN Scholar.

Domański Henryk. 2016. „Omniworyzm jedzenia i stratyfikacja społeczna”. Studia Socjologiczne 2: 123-143.

Douglas Mary, Baron Isherwood. 1979. The world of goods. Towards an anthropology of consumption. New York: W. W. Norton.

Erickson Bonnie H. 1996. "Culture, class, and connections". American Journal of Sociology 102(1): 217-251.

Gaag Van Der Martin, Tom A.B. Snijders. 2005. "The resource generator: Social capital qualification with concrete items". Social Networks 27(1): 1-29.

Granovetter Mark S. 1973. "The strength of weak ties". American Journal of Sociology 78(6): $1360-1380$.

Grodny Seweryn, Jerzy Gruszka, Kamil Luczaj. 2013. „O zawężeniu wyższego gustu estetycznego. Analiza zjawiska wszystkożerności kulturowej w Polsce”. Studia Socjologiczne 2: $127-148$.

Growiec Katarzyna. 2015. Ile szczęścia daja nam inni ludzie? Więzi spoleczne a dobrostan psychiczny. Warszawa: WN PWN.

Holt Douglas B. 1997. "Distinction in America? Recovering Bourdieu's theory of tastes from its critics". Poetics 25(2-3): 93-120.

Kandel Denise B. 1978. "Homophily, selection, and socialization in adolescent Friendships". American Journal of Sociology 84(2): 427-436.

Kane Danielle. 2004. "A network approach to the puzzle of women's cultural participation". Poetics 32(2): 105-127.

Lewis Kevin, Marco Gonzales, Jason Kaufman. 2012. "Social selection and peer influence in an online social network". Proceedings of the National Academy of Sciences 109(1): 68-72.

Lin Nan, Bonnie H. Erickson. 2008. Theory, measurement, and the research enterprise on social capital. In: Social capital. An international research program, N. Lin, B.H. Erickson (eds.), 1-24. Oxford: Oxford University Press.

Lin Nan. 1999. "Social networks and status attainment". Annual Review of Sociology 25: 467-487.

Lin Nan. 2000. "Inequality in social capital". Contemporary Sociology 29(6): 785-795.

Lin Nan. 2001. Social capital. A theory of social structure and action. Cambridge: Cambridge University Press. 
Lin Nan. 2008. A network theory of social capital. In: Handbook on social capital, D. Castiglione, J. van Deth, G. Wolleb (eds.), 50-69. Oxford: Oxford University Press.

Lizardo Omar, Sara Skiles. 2012. "Reconceptualizing and theorizing "omnivorousness": Genetic and relational mechanisms". Sociological Theory 30(4): 263-282.

Lizardo Omar. 2006. "How cultural tastes shape personal networks". American Sociological Review 71(5): 778-807.

Lizardo Omar. 2016. "Why 'cultural matters' matter: Culture talk as the mobilization of cultural capital in interaction". Poetics 58: 1-17.

Mark Noah. 1998. "Birds of a feather sing together". Social Forces 77(2): 453-485.

Marsden Peter V. 1987. "Core discussion networks of Americans". American Sociological Review 52(1): 122-131.

McPherson Miller, Lynn Smith-Lovin, Matthew E. Brashears. 2006. "Social isolation in America: Changes in Core discussion networks over two decades". American Sociological Review 71(3): 353-375.

Pabjan Barbara. 2009. Recepcja postaci i twórczości Chopina we współczesnym społeczeństwie polskim. W: Chopin w kulturze polskiej, M. Głąb (red.), 69-113. Wrocław: Wyd. UWr.

Peterson Richard A. 2005. "Problems in comparative research: The example of omnivorousness". Poetics 33(5-6): 257-282.

Peterson Richard A., Albert Simkus. 1992. How musical tastes mark occupational status groups. In: Cultivating differences, M. Lamont, M. Fournier (eds.), 152-186. Chicago: University of Chicago Press.

Peterson Richard A., Roger M. Kern. 1996. "Changing highbrow taste: From snob to omnivore". American Sociological Review 61(5): 900-907.

Petev Ivaylo D. 2013. "The association of social class and lifestyles: Persistence in American sociability, 1974 to 2010". American Sociological Review 78(4): 633-661.

Portes Alejandro. 1998. "Social capital: Its origins and applications in modern sociology". Annual Review of Sociology 24: 1-24.

Prior Nick. 2013. "Bourdieu and the sociology of music consumption: A critical assessment of recent developments". Sociology Compass 7(3): 181-193.

Puetz Kyle. 2015. "Consumer culture, taste preferences, and social network formation". Sociology Compass 9(6): 438-449.

Putnam Robert D. 2008. Samotna gra w kręgle. Upadek i odrodzenie wspólnot lokalnych w Stanach Zjednoczonych. Warszawa: WAiP.

Relish Michael. 1997. "It's not all education: Network measures as sources of cultural competency". Poetics 25(2-3): 121-139.

Roy William G., Timothy J. Dowd. 2010. "What is sociological about music?". Annual Review of Sociology 36: 183-203.

Savage Mike, Modesto Gayo. 2011. "Unravelling the omnivore: A field analysis of contemporary musical taste in the United Kingdom". Poetics 39(5): 337-357.

Tampubolon Gindo. 2008. "Distinction in Britain, 2001-2004? Unpacking homology and the 'aesthetics' of the popular class". European Societies 10(3): 403-428.

Tampubolon Gindo. 2010. "Social stratification and cultures hierarchy among the omnivores: Evidence from the Arts Council England surveys". The Sociological Review 58(1): 1-25.

Vaisey Stephen, Omar Lizardo. 2010. "Can cultural worldviews influence network composition?”. Social Forces 88(4): 1595-1618. 
Warde Alan, David Wright, Modesto Gayo-Cal. 2007. "Understanding cultural omnivorousness: Or, the myth of the cultural omnivore". Cultural Sociology 1(2): 143-164.

Warde Alan, Gindo Tampubolon. 2002. "Social capital, networks and leisure consumption". Sociological Review 50(2): 155-180.

Widdop Paul, Adrian Leguina. 2015. "With a Little help from my friends: Music consumption and networks". Sociologia, Revista da Faculdade de Letras da Universidade do Porto (volume tematico): 41-66.

Michat Cebula

\section{POZA KLASA SPOŁECZNĄ I STATUSEM. SIECIOWE ZAKORZENIENIE KONSUMPCJI MUZYKI}

Streszczenie

Związek między stratyfikacją a konsumpcją muzyki stał się dynamicznym polem badań w ostatnich latach nie tylko w socjologii muzyki, lecz w socjologii tout court. Przyjmuje się powszechnie, że konsumpcja muzyki przechodzi głęboką zmianę od ścisłej korespondencji między pozycjami społecznymi a gustem (teza o homologii) do modelu „wszystkożerności-jednożerności”, cechującego się większą różnorodnością preferencji wśród osób z wyższych warstw społecznych. Tym, co jest słabiej opisane w obu ujęciach, jest powiązanie konsumpcji muzyki z indywidualnymi sieciami społecznymi, niezależnie od innych zmiennych strukturalnych (np. klasy czy statusu). Bazując na oryginalnych danych ilościowych, autor próbuje ustalić, po pierwsze - czy zróżnicowanie osobistych sieci sprzyja większej różnorodności preferencji muzycznych i większej wiedzy, a po drugie, jaką role odgrywają ,słabe” i „silne” więzi. Potwierdzono, że ludzie, których sieci są bogatsze w słabsze połączenia, mają większe szanse bycia „wszystkożercami”, lecz ta zależność nie jest prawdziwa w odniesieniu do więzi silnych. Autor zarysowuje możliwe wyjaśnienia rezultatów oraz wskazuje kierunki przyszłych badań.

Słowa kluczowe: „wszystkożerność”, gusty muzyczne, sieci społeczne, kapitał społeczny, stratyfikacja kultury 